\title{
Yersinia pseudotuberculosis supports Th17 differentiation and limits de novo regulatory $T$ cell induction by directly interfering with $T$ cell receptor signaling
}

\author{
Maria Pasztoi $^{1} \cdot$ Agnes Bonifacius $^{1} \cdot$ Joern Pezoldt $^{1} \cdot$ Devesha Kulkarni $^{1} \cdot$ \\ Jana Niemz ${ }^{1} \cdot$ Juhao Yang $^{1} \cdot$ René Teich $^{1} \cdot$ Janina Hajek $^{2}$. Fabio Pisano ${ }^{2}$. \\ Manfred Rohde $^{3} \cdot$ Petra Dersch $^{2} \cdot$ Jochen Huehn $^{1}$
}

Received: 12 December 2016 / Revised: 20 March 2017 / Accepted: 28 March 2017 / Published online: 4 April 2017

(C) The Author(s) 2017. This article is an open access publication

\begin{abstract}
Adaptive immunity critically contributes to control acute infection with enteropathogenic Yersinia pseudotuberculosis; however, the role of $\mathrm{CD}^{+} \mathrm{T}$ cell subsets in establishing infection and allowing pathogen persistence remains elusive. Here, we assessed the modulatory capacity of $Y$. pseudotuberculosis on $\mathrm{CD}^{+} \mathrm{T}$ cell differentiation. Using in vivo assays, we report that infection with $Y$. pseudotuberculosis resulted in enhanced priming of IL17-producing $\mathrm{T}$ cells (Th17 cells), whereas induction of Foxp $3^{+}$regulatory $\mathrm{T}$ cells (Tregs) was severely disrupted in gut-draining mesenteric lymph nodes (mLNs), in line with altered frequencies of tolerogenic and proinflammatory dendritic cell (DC) subsets within mLNs. Additionally, by using a DC-free in vitro system, we could demonstrate that Y. pseudotuberculosis can directly modulate $\mathrm{T}$ cell receptor (TCR) downstream signaling within naïve $\mathrm{CD} 4^{+} \mathrm{T}$ cells and Tregs via injection of effector molecules through the type III secretion system, thereby affecting their functional properties. Importantly, modulation of naïve $\mathrm{CD} 4^{+} \mathrm{T}$ cells by $Y$. pseudotuberculosis resulted in an enhanced Th17 differentiation and decreased induction of Foxp $3^{+}$Tregs
\end{abstract}

Electronic supplementary material The online version of this article (doi:10.1007/s00018-017-2516-y) contains supplementary material, which is available to authorized users.

Jochen Huehn

jochen.huehn@helmholtz-hzi.de

1 Department Experimental Immunology, Helmholtz Centre for Infection Research, Inhoffenstrasse 7, 38124 Brunswick, Germany

2 Department Molecular Infection Biology, Helmholtz Centre for Infection Research, 38124 Brunswick, Germany

3 Central Facility for Microscopy, Helmholtz Centre for Infection Research, 38124 Brunswick, Germany in vitro. These findings shed light to the adjustment of the Th17-Treg axis in response to acute $Y$. pseudotuberculosis infection and highlight the direct modulation of $\mathrm{CD} 4^{+} \mathrm{T}$ cell subsets by altering their TCR downstream signaling.

Keywords Regulatory T cells $\cdot$ Th17 cells $\cdot$ Yersinia pseudotuberculosis $\cdot$ Intestinal infections $\cdot$ TCR signaling

$\begin{array}{ll}\text { Abbreviations } & \\ \text { Y.pseudotuberculosis } & \text { Yersinia pseudotuberculosis } \\ \text { mLN } & \text { Mesenteric lymph node } \\ \text { T3SS } & \text { Type III secretion system } \\ \text { Yops } & \text { Yersinia outer proteins } \\ \text { DC } & \text { Dendritic cell } \\ \text { Treg } & \text { Regulatory T cell } \\ \text { TCR } & \text { T cell receptor } \\ \text { Yptb-WT } & \text { Wild-type } Y \text {. pseudotuberculosis } \\ \text { Ova } & \text { Ovalbumin } \\ \text { APC } & \text { Antigen-presenting cell } \\ \text { TLR } & \text { Toll-like receptor }\end{array}$

\section{Introduction}

The intestinal immune system requires an extremely tight control as it is constantly exposed to high loads of harmless foreign antigens such as microbiota and food, while at the same time it has to be ready to mount rapid and efficient immune responses against invading pathogens. Among these pathogens, enteropathogenic Yersinia pseudotuberculosis is known to initially infect the terminal ileum and Peyer's patches, followed by an entering of mesenteric lymph nodes (mLNs). Infections with Y. pseudotuberculosis frequently result in the development of diarrhea, gastroenteritis, and mesenteric lymphadenitis [1, 2]. Yersiniae carry 
a broad range of virulence factors allowing interaction with immune cells and/or mediating immune evasion. Among others, they encode a type III secretion system (T3SS) on the pYV virulence plasmid, which enables translocation of effector proteins (Yops, Yersinia outer proteins) through a needle-like structure, referred to as injectisome [3]. Upon delivery into target cells, Yops (including YopE, H, J/P, $\mathrm{K}, \mathrm{M}, \mathrm{O}$, and $\mathrm{T}$ ) can interfere with intracellular signaling events, thereby manipulating key host cell functions such as cytokine secretion, actin cytoskeletal rearrangements, and phagocytosis $[4,5]$. Recently, we could demonstrate that efficient Yop delivery into target cells is supported by the cytotoxic necrotizing factor CNF $[$ [6].

While innate immunity represents a well-characterized part of the immune response against $Y$. pseudotuberculosis, involving neutrophils, macrophages, dendritic cells (DCs), and natural killer cells [7-10], the role of the adaptive immune system in combatting invading Yersiniae is only incompletely understood. Besides studies underpinning the importance of $\mathrm{CD}^{+} \mathrm{T}$ cells in control of Yersinia infection $[8,11,12]$, there are only few studies focusing on $\mathrm{CD}^{+} \mathrm{T}$ helper cell responses. These studies suggest the involvement of IFN $\gamma$-producing proinflammatory Th1 cells in protection against Yersinia [13], and report a capacity of $\mathrm{CD}^{+} \mathrm{T}$ cells in responding to $Y$. pseudotuberculosis superantigens in an MHCII-dependent manner [14]. A shift from immunoregulatory Foxp $3^{+}$regulatory $\mathrm{T}$ cells (Tregs) towards IL-17-producing proinflammatory Th17 cells has been reported for several enteropathogenic infections [15-18]. However, only little is known whether Yersiniae can directly modulate differentiation of $\mathrm{CD} 4^{+} \mathrm{T}$ cells, thereby favoring the establishment of infection $[9,19]$.

Here, we show that $Y$. pseudotuberculosis directly interacts with $\mathrm{CD}^{+} \mathrm{T}$ cells during the acute phase of infection and exemplify an involvement of Th17 cells and Tregs in the pathomechanism of disease. Using both de novo and in vitro $\mathrm{T}$ cell differentiation assays, we could demonstrate that T3SS-dependent modulation of $\mathrm{T}$ cells by $Y$. pseudotuberculosis results in a strongly impaired induction of Foxp $3^{+}$Tregs, while differentiation towards Th17 cells is highly supported. This immunological skewing of $\mathrm{T}$ cell differentiation is potentially mediated through the direct modulation of $\mathrm{T}$ cell receptor (TCR) downstream signaling pathways by the pathogen.

\section{Materials and methods}

\section{Mouse strains}

Foxp3 $3^{\text {hCD2 }} \times$ Rag2 $2^{-/-} \times$DO11.10 (BALB/c), Foxp $3^{\text {hCD2 }} \times$ CD90.1 (BALB/c), and Foxp3 $3^{\text {hCD2 }}$ (BALB/c) mice were bred and housed under specific pathogen-free conditions at the Helmholtz Centre for Infection Research (Braunschweig, Germany). BALB/c mice were purchased from Janvier. Gender- and age-matched mice were used in all experiments. Mice were housed and handled in accordance with recommendations of FELASA and the national animal welfare body GV-SOLAS guidelines. Experimental protocols were approved by the Lower Saxony Committee on the Ethics of Animal Experiments as well as the responsible state office (Lower Saxony State Office of Consumer Protection and Food Safety) under permit number 33.9-42502-04-13/1240.

\section{Antibodies and flow cytometry}

Fluorochrome-conjugated anti-B220 (RA3-6B2), antihCD2 (RPA-2.10), anti-CD3 (17A2), anti-CD4 (RM45), anti-CD8 (53-7.3), anti-CD11b (M1/70), anti-CD11c (N418), anti-CD19 (6D5), anti-CD25 (PC61.5), antiCD49b (DX5), anti-CD86 (GL1), anti-CD103 (2E7), antiF4/80 (BM8), anti-Foxp3 (FJK-16S), anti-IFN $\gamma$ (XMG1.2), anti-IL-10 (JES5-16E3), anti-IL-17 (TC11-18H10), antiLy6G (1A8), anti-MHCII (M5/114.15.2), anti-pERK1/2 (20 A), anti-ROR $\gamma t$ (AFKJS-9), and anti-Ova-TCR (KJ126) antibodies were purchased from BioLegend, eBioscience, and BD. Intracellular Foxp3/ROR $\gamma$ t and pERK1/2 stainings were performed according to the manufacturer's instructions (Foxp3 Staining Buffer Set, eBioscience and Phosflow $\mathrm{T}$ Cell Activation Kit, $\mathrm{BD}$, respectively). To determine the absolute number of living cells prior to flow cytometry analysis, propidium iodide (Sigma-Aldrich) was added, and cell number was determined using Accuri C6 Cytometer (BD). Dead cells were excluded based on the staining with the LIVE/DEAD Fixable Blue Dead Cell Stain (Thermo Fisher Scientific) and scatter properties. Cells were analyzed on LSRFortessa (BD) with Diva software v8.0.1 (BD), and data analysis was performed with FlowJo software v9.9.3 (TreeStar).

\section{Bacterial strains}

The YPIII wild-type Y. pseudotuberculosis strain (YptbWT) [20] carrying the pIB1 plasmid was used throughout the study. The strains YP173 (Yptb-WT-Bla) and YP174 $(\Delta \mathrm{T} 3 \mathrm{SS}-\mathrm{Bla})$ were constructed by chromosomal integration of the YopE- $\beta$-lactamase (ETEM) fusion plasmid pSR47s-E-TEM1 with Yptb-WT and the T3SS-mutant $\Delta \mathrm{yscS}$ strains [6]. Overnight cultures of Yersiniae strains were grown at $25^{\circ} \mathrm{C}$ in Luria-Bertani broth medium (BD), washed, and diluted in PBS prior to infection. For in vitro co-culture experiments, bacteria were diluted 1:50 after overnight incubation, followed by incubation for $2 \mathrm{~h}$ at $25^{\circ} \mathrm{C}$ and additional cultivation for $3 \mathrm{~h}$ at $37^{\circ} \mathrm{C} .50 \mu \mathrm{g} /$ 
$\mathrm{ml}$ kanamycin (Sigma-Aldrich) was used for bacterial selection.

\section{Mouse infection}

Female BALB/c mice (Janvier) aged between 6 and 7 weeks were subjected to fasting for $16 \mathrm{~h}$ prior to infection. Subsequently, mice were orally infected with $2 \times 10^{8}$ Yptb-WT using a ball-tipped gavaging needle. 2 days p.i., the frequency of neutrophils in the peripheral blood of infected and non-infected mice was analyzed by flow cytometry, and significantly increased mobilization of neutrophils into peripheral blood of infected mice was taken as an indicator of a successful infection (data not shown). In general, body-weight loss and signs of severe illness of mice infected with $2 \times 10^{8}$ Yptb-WT peaked at day 5-6. At indicated time points p.i., infected mice were analyzed or subjected to further experimental procedures.

\section{In vivo $T$ cell differentiation assay}

For adoptive transfer, single cell suspensions were generated from spleens and LNs of Foxp $3^{\mathrm{hCD} 2} \times \mathrm{Rag} 2^{-/-} \mathrm{xDO} 11.10$ mice. Before transfer, cells were labeled with the proliferation dye Cell Trace ${ }^{\mathrm{TM}}$ Violet (CTV, Thermo Fisher Scientific), and $4 \times 10^{6}$ cells were injected in $100 \mu$ PBS i.v. per recipient mouse. For induction of $\mathrm{T}$ cell differentiation, $20 \mu \mathrm{g} \mathrm{Ova}_{323-339}$ peptide was injected i.v. on two consecutive days, starting 1 day after adoptive $T$ cell transfer. At day 3 after the first antigen application, cells were isolated from $\mathrm{mLNs}$ and stained for flow cytometric analysis. Intracellular cytokine staining was performed after restimulation with phorbol 12-myristate 13-acetate (PMA)/ionomycin for $2 \mathrm{~h}$ (10 and $500 \mathrm{ng} / \mathrm{ml}$, respectively) and with $10 \mu \mathrm{g} /$ $\mathrm{ml}$ Brefeldin A for additional $2 \mathrm{~h}$ at $37^{\circ} \mathrm{C}$ (all from SigmaAldrich), followed by fixation and standard staining of surface markers.

\section{Field emission scanning electron microscopy (FESEM)}

Total $\mathrm{CD}^{+}{ }^{+} \mathrm{T}$ cells were enriched from spleens and LNs of BALB/c mice using CD4 (L3T4) MicroBeads and autoMACS separation (Miltenyi Biotec). $\mathrm{CD}^{+} \mathrm{T}$ cells were co-cultured with Yptb-WT for $1 \mathrm{~h}$ at MOI (multiplicity of infection) 100, followed by washing. Fixation was performed by $1 \mathrm{~h}$ incubation and washing with cacodylat buffer. Cells were placed on poly-L-lysine-coated cover slips, followed by fixation with $3 \%$ glutaraldehyde and washed with TE-buffer (0.02 M Tris, $0.001 \mathrm{M}$ EDTA, pH 7.0), dehydrated with a graded series of acetone $(10,30$, $50,70,90,100 \%$ ), and critical-point dried. After sputter coating with a gold film (appr. $10 \mathrm{~nm}$ ), samples were analyzed using a Zeiss DSM 982 Gemini FESEM.

\section{$\beta$-Lactamase reporter assay}

For in vivo analysis of Yop translocation, BALB/c mice were infected intragastrically with $2 \times 10^{9}$ Yptb-WT-Bla. At day 3 , single cell suspensions of mLNs were stained for cell surface markers and subsequently labeled with CCF4-AM, using the LiveBLAzer-FRET B/G Loading Kit (Thermo Fisher Scientific) for $1 \mathrm{~h}$ at room temperature in the presence of $1.5 \mathrm{mM}$ probenecid (SigmaAldrich) and $50 \mu \mathrm{g} / \mathrm{ml}$ gentamicin (Sigma-Aldrich). To study Yop translocation in vitro, naïve $\mathrm{CD}^{+} \mathrm{T}$ cells were isolated from spleen and LNs of Foxp $3^{\mathrm{hCD} 2}$ mice. Briefly, cells were stained with anti-CD25-APC and antihCD2-APC, followed by a depletion of $\mathrm{APC}^{+}$cells using anti-APC MicroBeads (Miltenyi Biotec) and autoMACS separation system. Subsequently, $\mathrm{CD} 4^{+} \mathrm{T}$ cells were magnetically sorted as described before. The resulting naïve Foxp $3{ }^{\text {hCD2}}{ }^{-} \mathrm{CD} 62 \mathrm{~L}^{\text {hi }} \mathrm{CD} 44^{\text {lo }} \mathrm{CD} 25^{-} \mathrm{CD} 4^{+} \mathrm{T}$ cells were cocultured with Yptb-WT-Bla or $\Delta$ T3SS-Bla at an MOI of 10 for $1 \mathrm{~h}$ at $37^{\circ} \mathrm{C}$, washed twice with RPMI supplemented with $50 \mu \mathrm{g} / \mathrm{ml}$ gentamicin to eliminate bacteria. Subsequently, $2 \times 10^{6}$ cells were labeled with CCF4-AM and analyzed by flow cytometry.

\section{$\mathrm{Ca}^{2+}$ signaling measurement}

Total $\mathrm{CD} 4{ }^{+} \mathrm{T}$ cells were enriched from spleens and LNs of Foxp $3^{\text {hCD2 }}$ mice via autoMACS separation. MACS-separated $\mathrm{CD} 4^{+} \mathrm{T}$ cells were co-cultured with Yptb-WT-Bla and $\Delta$ T3SS-Bla strains at MOI of 50 for $1 \mathrm{~h}$ at $37^{\circ} \mathrm{C}$ and washed twice with gentamicin-containing RPMI. Subsequently, cells were stained for CD4 and Foxp $3^{\text {hCD2}}$, loaded with $4 \mu \mathrm{g} / \mathrm{ml}$ Indo- 1 AM cell permanent dye (Thermo Fisher Scientific) at $37^{\circ} \mathrm{C}$ for $45 \mathrm{~min}$ in dark, followed by pre-decoration with $18 \mu \mathrm{g} / \mathrm{ml}$ anti-CD3-Biotin and $1 \mu \mathrm{g} /$ $\mathrm{ml}$ anti-CD28-Biotin (both from BD). TCR crosslinking was induced by the addition of $40 \mu \mathrm{g} / \mathrm{ml}$ Streptavidin (Dianova) to the pre-warmed cell suspension. Ionomycin at $4 \mu \mathrm{g} / \mathrm{ml}$ concentration served as positive control providing maximum $\mathrm{Ca}^{2+}$ influx. The $\mathrm{Ca}^{2+}$ signal was measured in the respective gates of Tregs and naïve $\mathrm{T}$ cells by flow cytometry.

\section{pERK staining}

Total $\mathrm{CD} 4^{+} \mathrm{T}$ cells were enriched from spleens and LNs of Foxp $3^{\text {hCD2}}$ mice by autoMACS separation. MACS-separated $\mathrm{CD}^{+}{ }^{+} \mathrm{T}$ cells were co-cultured with Yptb-WT-Bla and $\Delta$ T3SS-Bla strains at MOI of 50 for $1 \mathrm{~h}$ at $37^{\circ} \mathrm{C}$ and washed twice with gentamicin-containing RPMI. Subsequently, cells were first stained with LIVE/DEAD Fixable Blue Dead Cell Stain and anti-CD4 antibody, followed by decoration with $10 \mu \mathrm{g} / \mathrm{ml}$ anti-CD3-Biotin and $5 \mu \mathrm{g} / \mathrm{ml}$ 
anti-CD28-Biotin antibodies for $15 \mathrm{~min}$ on ice. Crosslinking was induced by the addition of $10 \mu \mathrm{g} / \mathrm{ml}$ Streptavidin to the pre-warmed cell suspensions. At indicated time points, cells were fixed and permeabilized, followed by intracellular staining with anti-pERK1/2 and anti-Foxp3 antibodies overnight at $4{ }^{\circ} \mathrm{C}$. Next, ERK phosphorylation was determined in the respective gates of live $\mathrm{CD} 4{ }^{+} \mathrm{Foxp} 3$ naïve $\mathrm{T}$ cells and $\mathrm{CD} 4^{+} \mathrm{Foxp}^{+}$Tregs.

\section{In vitro $T$ cell differentiation assay}

Naïve CD4 ${ }^{+} \mathrm{T}$ cells were isolated from spleen and LNs of Foxp $3^{\mathrm{hCD} 2}$ mice as described before. The resulting naïve Foxp $3{ }^{\text {hCD2- }}{ }^{-}$D62 $2{ }^{\text {hi }} \mathrm{CD} 44^{\text {lo }} \mathrm{CD} 25^{-} \mathrm{CD} 4{ }^{+} \mathrm{T}$ cells were cocultured with Yptb-WT-Bla and $\Delta$ T3SS-Bla at an MOI of 50 for $1 \mathrm{~h}$ at $37^{\circ} \mathrm{C}$. After the removal of bacteria by washing with gentamicin-containing RPMI, cells were cultured under Th0, Th1, Th17, or Treg-polarizing conditions. For Treg cultures, $5 \times 10^{5}$ cells/well were cultured on 96-well round-bottom plates in RPMI supplemented with $10 \mathrm{ng} /$ $\mathrm{ml}$ IL-2 (R\&D), $5 \mathrm{ng} / \mathrm{ml}$ TGF- $\beta 1$ (R\&D), $50 \mu \mathrm{g} / \mathrm{ml}$ gentamicin, and anti-CD3/CD28 Dynabeads Mouse T Activator (Thermo Fisher Scientific) at 1:1 ratio. Frequency of Foxp $3^{\mathrm{hCD} 2+}$ cells was determined 4 days later. For Th17 culture conditions, $2 \times 10^{6}$ cells/well were cultured in 24-well plates coated with $3 \mu \mathrm{g} / \mathrm{ml}$ anti-CD3 (BioLegend) and $5 \mu \mathrm{g} / \mathrm{ml}$ anti-CD28 (eBioscience) in IMDM supplemented with $2 \mathrm{ng} / \mathrm{ml}$ TGF- $\beta 1,30 \mathrm{ng} / \mathrm{ml} \mathrm{IL-} 6,10 \mathrm{ng} / \mathrm{ml}$ IL- $1 \beta, 5 \mu \mathrm{g} / \mathrm{ml}$ anti-IL-2, $20 \mathrm{ng} / \mathrm{ml}$ TNF- $\alpha$ (all from BioLegend), $10 \mu \mathrm{g} / \mathrm{ml}$ anti-IFN- $\gamma$ (BioXCell), and $50 \mu \mathrm{g} / \mathrm{ml}$ gentamicin for 4 days. Then, cells were replated in fresh medium and cultured without TCR stimulation for two additional days. On day 6 , frequency of $\mathrm{IL}-17^{+}$cells was determined after restimulation and fixation as described before. For Th 0 and Th1 cultures conditions, $2 \times 10^{6}$ cells/ well were cultured in 24-well plates coated with $2 \mu \mathrm{g} / \mathrm{ml}$ anti-CD3 and anti-CD28 in IMDM containing $50 \mu \mathrm{g} / \mathrm{ml}$ gentamicin. The Th1 culture medium was supplemented with $20 \mathrm{ng} / \mathrm{ml} \mathrm{IL-12} \mathrm{(PeproTech)} \mathrm{and} 10 \mu \mathrm{g} / \mathrm{ml}$ anti-IL-4 (BioLegend), whereas cells cultured under Th0 conditions did not receive any cytokines or neutralizing antibodies. Cells were replated in fresh medium on day 2 and cultured without TCR stimulation for three additional days. On day 5 , frequency of IFN- $\gamma^{+}$cells was determined after restimulation and fixation, as described before.

\section{Statistical analysis}

Group sizes were estimated according to a presumed standard deviation (SD) and an expected type I error of $<0.05$. The sample size was adjusted, if required, based on initial results. For all figures, each data point represents a single mouse if not stated otherwise. For comparison of unmatched groups, two-tailed Mann-Whitney statistical test was applied. The comparison of more than two groups was performed by one-way ANOVA followed by Bonferroni's post-test. All data are presented as mean or mean $\pm \mathrm{SD}$, and $p$ values $<0.05$ are considered as significant $\left({ }^{*} p<0.05\right.$; $* * p<0.01 ; * * * p<0.001 ; * * * * p<0.0001)$. Prism software (GraphPad, La Jolla, CA, USA) was applied for all statistical analyses and graphs.

\section{Results}

\section{Acute $Y$. pseudotuberculosis infection impairs de novo Treg induction and favors Th17 differentiation}

The role of immunoregulatory Foxp $3^{+}$Tregs and proinflammatory Th17 cells in combatting acute Yersiniae infections is only incompletely understood $[9,19]$. Thus, we first assessed whether acute infection with $Y$. pseudotuberculosis has an effect on the peripheral de novo generation of these two opposing $\mathrm{T}$ cell subsets. Since gut-draining mLNs are among the first target organs of $Y$. pseudotuberculosis, we decided to focus on $\mathrm{T}$ cell differentiation events taking place within mLNs. Thereto, BALB/c mice were infected sublethally with wild-type $Y$. pseudotuberculosis (YptbWT). At day 2 post infection (p.i.), shortly before the infection reaches its peak, TCR-transgenic, ovalbumin (Ova)specific naïve Foxp $3^{-} \mathrm{CD} 4^{+} \mathrm{T}$ cells were labeled with a cell proliferation dye and adoptively transferred into infected mice, while uninfected recipient mice served as controls (Fig. 1a). Subsequently, adoptively transferred naïve $\mathrm{T}$ cells were primed by systemic application of Ova peptide via the i.v. route on two consecutive days as reported previously [21]. At day 3 after the first antigen application, proliferating Ova-specific T cells within mLNs of uninfected and Yptb-WT-infected mice were analyzed by flow cytometry (Fig. 1b, c). As expected from previous observations [21], a high frequency of de novo-induced Foxp $3^{+}$Tregs among adoptively transferred $\mathrm{T}$ cells was observed in mLNs of uninfected mice. Importantly, de novo Treg induction was dramatically reduced in mLNs of mice infected with YptbWT (Fig. 1b). In parallel, the frequency of IL-17-producing cells among adoptively transferred $\mathrm{Ova}-\mathrm{TCR}^{+} \mathrm{CD} 4^{+} \mathrm{T}$ cells, albeit being at a low level, was significantly higher upon infection with Yptb-WT when compared to uninfected controls (Fig. 1c), in line with a significant increase in IL-17-producing endogenous $\mathrm{CD}^{+} \mathrm{T}$ cells at day 8 p.i. (Supplementary Fig. S1). In contrast to this increase in IL-17-producing T cells, the frequency of IFN- $\gamma$ - and IL-10-producing endogenous $\mathrm{CD}^{+} \mathrm{T}$ cells remained unchanged during the first 12 days p.i. (Supplementary Figure S1), further supporting the important contribution of Th17 cells to the control of $Y$. pseudotuberculosis infection 


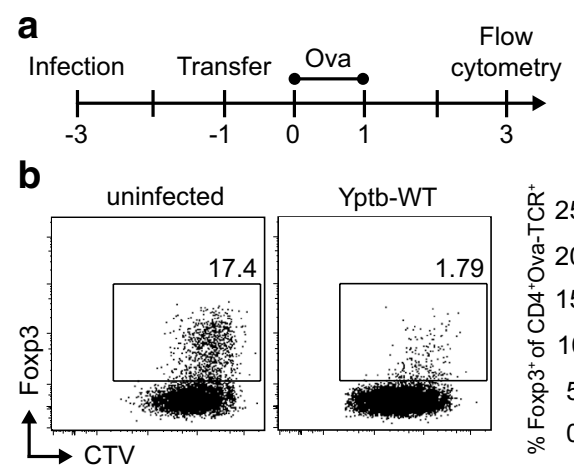

low

b

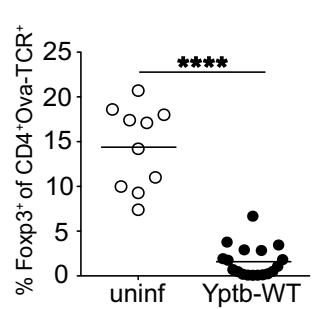

C
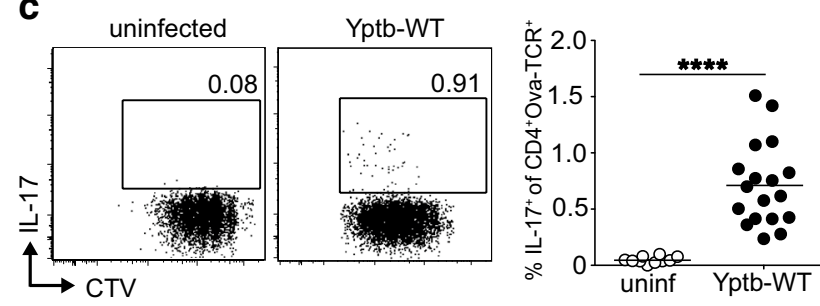

Fig. 1 Abrogation of de novo Treg induction and increased Th17 differentiation during acute $Y$. pseudotuberculosis infection. a BALB/c mice were infected with $2 \times 10^{8}$ Yptb-WT, and received $4 \times 10^{6} \mathrm{CTV}$ labeled cells from Foxp $3^{\mathrm{hCD} 2} \mathrm{xRag} 2^{-/-} \mathrm{xDO} 11.10$ mice 2 days p.i. Uninfected mice were taken as controls. On the following 2 days, recipients were immunized via i.v. injection of $\mathrm{Ova}_{323-339}$ peptide and analyzed on day 3 after the first immunization by flow cytometry. $\mathbf{b}$, c Representative dot plots show expression of Foxp3 b or IL-17 c over cell division (as indicated by loss of CTV) on adoptively transferred $\mathrm{CD}^{+}{ }^{+} \mathrm{Ova}-\mathrm{TCR}^{+} \mathrm{T}$ cells in $\mathrm{mLN}$ from Yptb-WT-infected mice or uninfected controls. Numbers indicate frequencies of cells in gates. Scatter plots summarize frequencies of Foxp $3^{+}(\mathbf{b})$ or $\mathrm{IL}_{1} 7^{+}(\mathbf{c})$ cells among adoptively transferred $\mathrm{CD}^{+} \mathrm{Ova}-\mathrm{TCR}^{+} \mathrm{T}$ cells from indicated groups. Data are pooled from three independent experiments, each with 3-5 mice per group. $* * * * p<0.0001$

[22]. Together, these results indicate that acute $Y$. pseudotuberculosis infection shifts the immunological balance from immunoregulatory towards proinflammatory $\mathrm{T}$ cells, thereby favoring the establishment of a protective, inflammatory environment in the intestine.

\section{Yersinia pseudotuberculosis infection alters composition of the DC compartment}

It is widely accepted that DCs play a key role for de novo induction of both Foxp3 ${ }^{+}$Tregs [21, 23] and Th17 cells [24]. Since gastrointestinal inflammation can strongly modify the DC compartment within mLNs, resulting in reduced tolerogenic properties of DCs [25], we next aimed to explore whether DC subsets were substantially altered within mLNs during acute infection with $Y$. pseudotuberculosis, and might contribute to the observed shift from Tregs to Th17 cells. At day 5 p.i., the overall frequency of MHCII ${ }^{\text {hi }} \mathrm{CD} 11 \mathrm{c}^{\text {hi }}$ conventional DCs (cDCs) was strongly reduced in mLNs of mice infected with Yptb-WT (Supplementary Fig. S2a, b). However, absolute numbers of cDCs within mLNs did not change significantly when comparing infected mice to uninfected controls (Supplementary Fig. S2c). Nevertheless, we could observe a substantial alteration among specialized subsets within the cDC compartment. Tolerogenic $\mathrm{CD} 103^{+} \mathrm{CD} 8^{+} \mathrm{cDCs}$, known to be involved in de novo Treg induction [21, 23, 26, 27], were strongly reduced upon infection with Yptb-WT, whereas CD103-CD8 ${ }^{-}$cDCs, which have been described to be responsible for priming of Th1 and/or Th17 cells [24], were significantly expanded (Fig. 2a-c). Importantly, $\mathrm{CD} 103^{-} \mathrm{CD}^{-}{ }^{-} \mathrm{cDCs}$ displayed a strong increase in CD86 expression upon infection with Yptb-WT (Fig. 2d, e), reflecting their activated phenotype. Taken together, acute $Y$. pseudotuberculosis infection strongly affects the cDC compartment, and leads to a partial contraction of tolerogenic $\mathrm{CD}_{103}{ }^{+} \mathrm{CD}^{+} \mathrm{cDCs}$, which might be responsible for the observed reduction of de novo Treg induction, while the expansion of $\mathrm{CD} 103^{-} \mathrm{CD} 8^{-} \mathrm{cDCs}$ supports our initial observation of a shift towards Th17 differentiation.

\section{Yersinia pseudotuberculosis directly targets $\mathrm{CD4}^{+} \mathrm{T}$ cell subsets}

Our hitherto existing results suggested that acute $Y$. pseudotuberculosis infection causes an alteration of the Th17Treg balance by strongly affecting the cDC compartment. However, in addition to these indirect effects on T cell differentiation, more direct effects on $\mathrm{T}$ cell fate decisions are conceivable. Thus, we next asked whether $Y$. pseudotuberculosis could also directly interact with $\mathrm{CD} 4^{+} \mathrm{T}$ cells. At first, we performed field emission scanning electron microscopy analyses after co-culturing naïve $\mathrm{CD}^{+} \mathrm{T}$ cells with Yptb-WT in vitro and observed a direct attachment of Yersiniae to naïve $\mathrm{T}$ cells (Fig. 3a). In order to identify $\mathrm{CD} 4^{+}$ $\mathrm{T}$ cell subsets being targeted by $Y$. pseudotuberculosis, we next applied a $\beta$-lactamase reporter assay [28, 29]. To this end, a Yptb-WT strain variant was generated via chromosomal integration of a YopE- $\beta$-lactamase fusion plasmid. This strain, named Yptb-WT-Bla, allows the assessment of Yop translocation into cells loaded with the cell permeable, $\beta$-lactamase-sensitive dye CCF4-AM [28, 29], resulting in a fluorescence shift from green to blue (Fig. 3b). In vitro co-culture of $\mathrm{CD} 25^{\text {hi }} \mathrm{CD}^{+}$Tregs with Yptb-WT-Bla resulted in slightly higher translocation frequency as compared to naïve $\mathrm{CD}^{+}{ }^{+} \mathrm{T}$ cells (data not shown). To monitor in vivo Yop translocation and to identify $\mathrm{CD} 4^{+} \mathrm{T}$ cell subsets being modulated by $Y$. pseudotuberculosis, BALB/c mice were infected sublethally with Yptb-WT-Bla. At day 3 p.i., the frequency of modulated cells among naïve $\mathrm{CD} 4^{+}$ $\mathrm{T}$ cells and $\mathrm{CD} 25^{\mathrm{hi}} \mathrm{CD} 4^{+}$Tregs from $\mathrm{mLNs}$ was analyzed by flow cytometry. The $\beta$-lactamase reporter assay revealed 


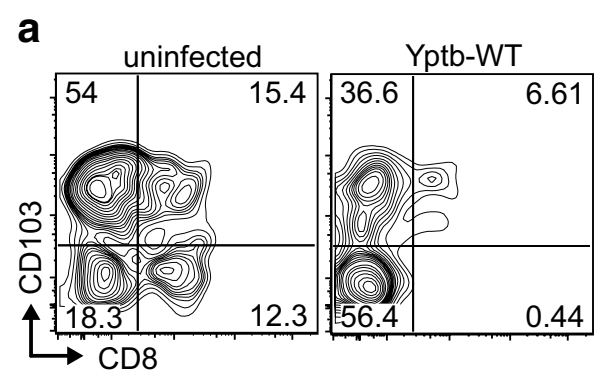

C

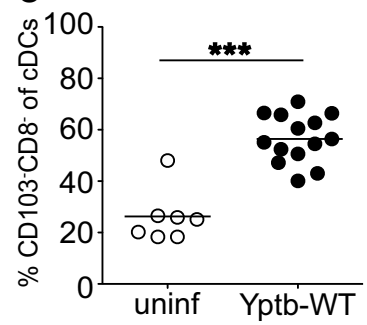

d

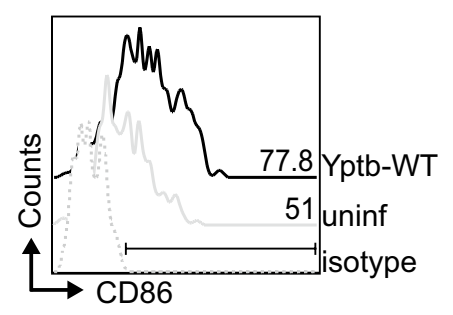

b

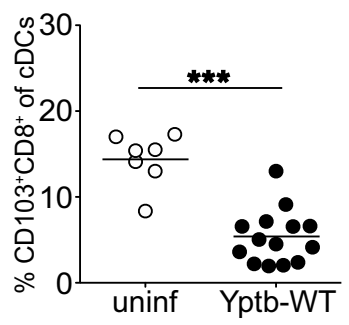

Fig. 2 Acute $Y$. pseudotuberculosis infection results in decreased frequencies of tolerogenic $\mathrm{CD} 103^{+} \mathrm{CD}^{+} \mathrm{DCs}$, and expansion of proinflammatory $\mathrm{CD}_{103^{-}}$DCs. BALB/c mice were infected with $2 \times 10^{8}$ Yptb-WT, and on day 5 p.i. cDC subsets within $\mathrm{mLNs}$ were analyzed by flow cytometry. Uninfected mice were taken as controls. a Representative dot plots depict CD8 and CD103 expression of $\mathrm{Lin}^{-}\left(\mathrm{CD} 3^{-} \mathrm{CD} 19^{-} \mathrm{CD} 49 \mathrm{~b}^{-} \mathrm{B} 220^{-}\right) \mathrm{CD} 11 \mathrm{c}^{\mathrm{hi}} \mathrm{MHCII}^{\mathrm{hi}} \mathrm{cDCs}$ in $\mathrm{mLN}$ from Yptb-WT-infected mice or uninfected controls. Numbers indicate frequencies of cells in gates. b, c Scatter plots summarize the frequencies of $\mathrm{CD} 103^{+} \mathrm{CD}^{+}$cells (b) and $\mathrm{CD} 103^{-} \mathrm{CD} 8^{-}$cells (c) among cDCs from indicated groups. d Representative histograms depict CD86 expression of $\mathrm{CD}^{-} \mathrm{CD}^{-} 103^{-}$cDC subset from indicated groups. The region was set according to isotype control staining, and numbers indicate frequencies of $\mathrm{CD} 86^{+}$cells. e Scatter plot summarizes frequencies of $\mathrm{CD} 86^{+}$cells among $\mathrm{CD} 8^{-} \mathrm{CD} 103^{-} \mathrm{cDC}$ subset from indicated groups. Data are pooled from two independent experiments, each with 3-7 mice per group. $* * * p<0.001$ a

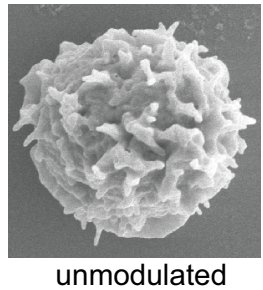

C

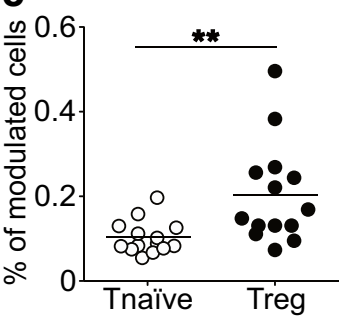

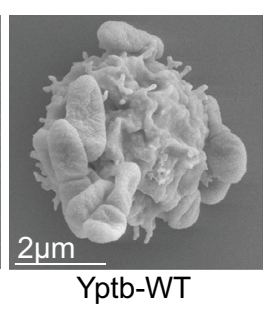

d b

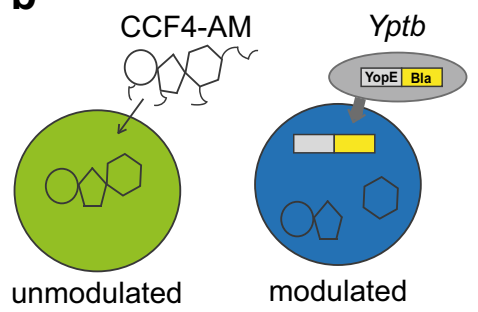

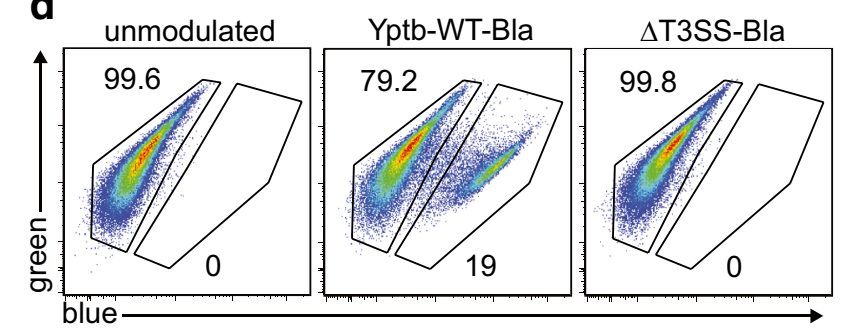

Fig. 3 Y. pseudotuberculosis directly targets $\mathrm{CD}^{+} \mathrm{T}$ cell subsets. a Scanning electron microscopy of unmodulated and Yptb-WT-modulated naïve $\mathrm{CD}^{+} \mathrm{T}$ cells; representative pictures taken from one experiment. b Scheme of the $\beta$-lactamase reporter assay: upon Yop translocation into cells loaded with CCF4-AM, the $\beta$-lactamasesensitive dye is cleaved, resulting in a fluorescence shift from green to blue. c Scatter plot depicts frequency of $Y$. pseudotuberculosismodulated $\mathrm{CD} 25^{-} \mathrm{CD} 4^{+}$naïve $\mathrm{T}$ cells and $\mathrm{CD} 25^{\mathrm{hi}} \mathrm{CD} 4^{+}$Tregs in $\mathrm{mLNs}$ assessed 3 days after intragastric infection of BALB/c mice with $2 \times 10^{9}$ Yptb-WT-Bla. Data are pooled from two independent experiments, each with $6-7$ mice per group. ${ }^{* *} p<0.01$. d Ex vivoisolated naïve $\mathrm{CD} 4^{+} \mathrm{T}$ cells were co-cultured with Yptb-WT-Bla or $\Delta \mathrm{T} 3 \mathrm{SS}$-Bla for $1 \mathrm{~h}$ or were left unmodulated as control. The frequencies of Y. pseudotuberculosis-modulated cells were analyzed by flow cytometry utilizing the $\beta$-lactamase reporter assay. Representative dot plots demonstrate the shift in fluorescence from green to blue in Yptb-WT-Bla-modulated cells (middle panel), or lack of blue cells in unmodulated and $\Delta$ T3SS-Bla-modulated cells (left and right panels, respectively) 
that the frequency of in vivo-modulated Tregs, albeit being at a low level, was significantly higher when compared to naïve $\mathrm{CD}^{+}{ }^{+} \mathrm{T}$ cells (Fig. 3c). To assess the role of the T3SS in modulating $\mathrm{CD}^{+} \mathrm{T}$ cells, a variant of the $\Delta \mathrm{yscS}$ T3SS mutant strain [6], named $\Delta \mathrm{T} 3 \mathrm{SS}-\mathrm{Bla}$, was generated via chromosomal integration of the YopE- $\beta$-lactamase fusion plasmid. After in vitro co-culture of naïve $\mathrm{CD}^{+} \mathrm{T}$ cells with $\Delta \mathrm{T} 3 \mathrm{SS}-\mathrm{Bla}$, all modulated cells fully retained their green fluorescence, in contrast to Yptb-WT-Bla-modulated cells showing a substantial fraction of blue cells (Fig. 3d). In conclusion, the $\beta$-lactamase reporter assay enabled to demonstrate direct targeting of $\mathrm{CD} 4^{+} \mathrm{T}$ cell subsets, particularly Tregs, by $Y$. pseudotuberculosis in vivo. Moreover, the $\Delta$ T3SS-Bla strain proved to be helpful to further dissect alterations in $\mathrm{T}$ cell functional properties affected by the T3SS.

\section{Yersinia interferes with TCR-induced $\mathrm{Ca}^{2+}$ signaling and ERK phosphorylation within both naïve $T$ cells and Tregs}

As translocation of Yops can modulate host cell signaling responses [4], we next aimed to unravel downstream events of TCR signaling influenced by $Y$. pseudotuberculosis. First, we analyzed intracellular $\mathrm{Ca}^{2+}$ flux in $\mathrm{CD}^{+} \mathrm{T}$ cells stimulated via their TCR by using Indo-1 AM cell permeable dye as a rapid and sensitive measure of TCR activation. TCR crosslinking was induced via the addition of streptavidin to cells pre-decorated with biotinylated anti-CD3/CD28 antibodies. Similar to what has been reported before [30], TCR-triggered $\mathrm{Ca}^{2+}$ signaling of naïve $\mathrm{CD}^{+} \mathrm{T}$ cells was profoundly higher as compared to Foxp $3^{+}$Tregs (Fig. 4a). Interestingly, after co-culture with Yptb-WT for $1 \mathrm{~h}$, naïve

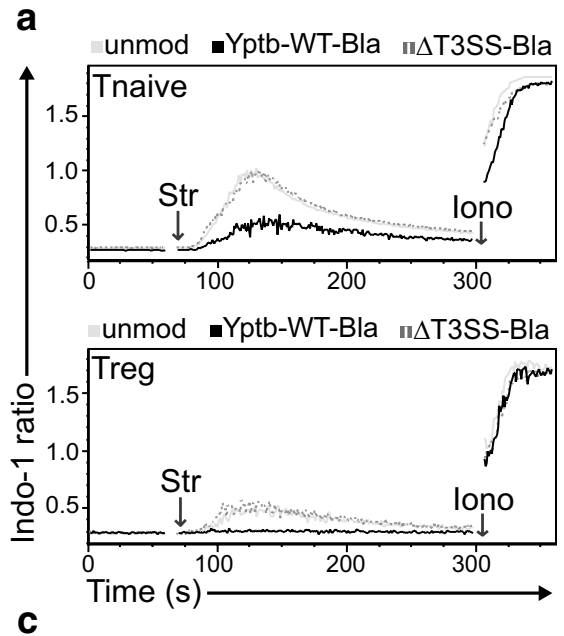

b
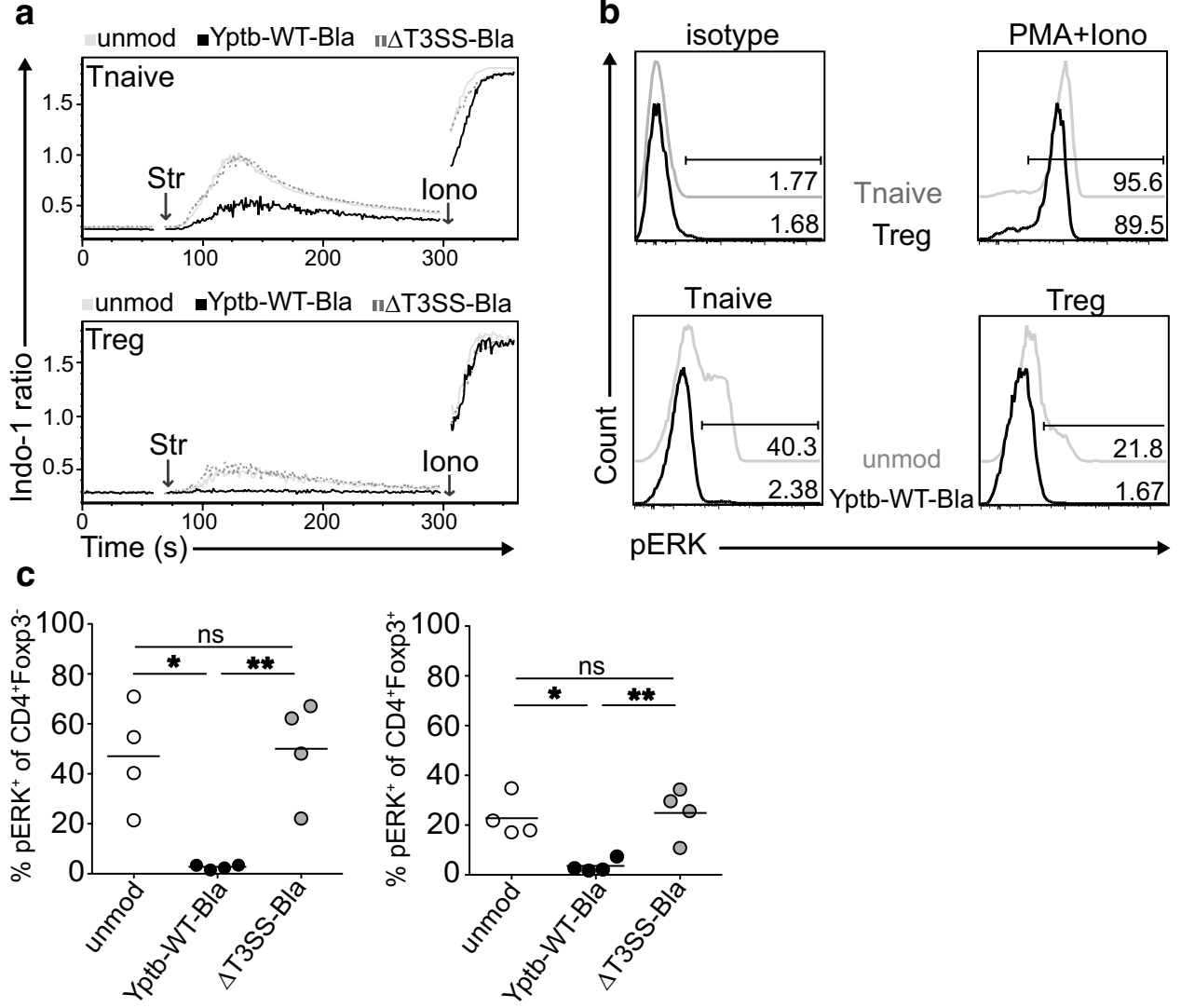

Fig. $4 Y$. pseudotuberculosis modulates naïve $\mathrm{T}$ cells and Tregs by interfering with TCR downstream signaling pathways. $\mathrm{CD} 4^{+} \mathrm{T}$ cells were enriched from secondary lymphoid organs of Foxp $3^{\mathrm{hCD} 2}$ mice and co-cultured with Yptb-WT-Bla or $\Delta$ T3SS-Bla for $1 \mathrm{~h}$. Subsequently, TCR crosslinking of anti-CD3/CD28 pre-decorated cells was induced by addition of streptavidin (Str). a Intracellular $\mathrm{Ca}^{2+}$ flux was assessed in Foxp $3^{\text {hCD2- }}$ naïve $\mathrm{T}$ cells and Foxp $3^{\mathrm{hCD} 2+}$ Tregs by flow cytometry using the cell permeable Indo- $1 \mathrm{AM}$ dye. $\mathrm{Ca}^{2+}$ flux in response to the positive control ionomycin (Iono) was equivalent between all groups. Histograms show representative results of three independent experiments. b Phosphorylation of ERK was assessed
1.5 min after TCR crosslinking by intracellular pERK staining and flow cytometry in Foxp $3^{\text {hCD2- }}$ naïve $T$ cells and Foxp $3^{\text {hCD2+ }}$ Tregs. Representative histograms depict pERK expression of gated cells from indicated groups, and numbers indicate frequencies of $\mathrm{pERK}^{+}$ cells. The region was set according to isotype control staining of unmodulated cells (upper left). Stimulation of cells with PMA plus Iono served as positive control (upper right). c Scatter plots summarize frequencies of $\mathrm{pERK}^{+}$cells among Foxp $3^{\mathrm{hCD} 2-}$ naïve $\mathrm{CD} 4^{+} \mathrm{T}$ cells (left) and Foxp $3^{\text {hCD2+ }}$ Tregs (right). Data are pooled from four independent experiments. Ns not significant; ${ }^{*} p<0.05$; $* *<0.01$ 
$\mathrm{CD}^{+} \mathrm{T}$ cells showed a strong reduction in $\mathrm{Ca}^{2+}$ signaling, while $\mathrm{Ca}^{2+}$ flux into Foxp3 ${ }^{+}$Tregs even was completely blocked. This interference with TCR-induced $\mathrm{Ca}^{2+}$ signaling was strictly dependent on the T3SS as modulation of $\mathrm{CD}^{+}{ }^{+} \mathrm{T}$ cells with $\Delta \mathrm{T} 3 \mathrm{SS}-\mathrm{Bla}$ did not alter $\mathrm{Ca}^{2+}$ signaling within both $\mathrm{CD}^{+} \mathrm{T}$ cells and Foxp3 $3^{+}$Tregs (Fig. 4a), suggesting that translocation of Yops critically contribute to the modulation of TCR downstream signaling. Secondly, we measured TCR-induced phosphorylation of ERK (pERK), a more specific indicator of TCR activation, after the modulation of naïve $\mathrm{CD} 4^{+} \mathrm{T}$ cells with $Y$. pseudotuberculosis. Kinetic studies ( $0-5$ min after TCR crosslinking) revealed that the peak of ERK phosphorylation occurred after $1.5 \mathrm{~min}$ (data not shown), and this time point was chosen for all further analyses. In accordance with published data [30], unmodulated naïve $\mathrm{CD}^{+}{ }^{+} \mathrm{T}$ cells showed a higher frequency of $\mathrm{pERK}^{+}$cells as compared to unmodulated Foxp $3^{+}$Tregs, while both cell types showed strong pERK activation upon stimulation with PMA and ionomycin (Fig. 4b). Upon modulation with Yptb-WT, ERK phosphorylation was completely abrogated in both naïve $\mathrm{CD} 4^{+}$ $\mathrm{T}$ cells and Foxp $3^{+}$Tregs, and again this interference with TCR-induced signaling was strictly dependent on the T3SS as modulation of $\mathrm{CD}^{+}{ }^{+} \mathrm{T}$ cells with $\Delta \mathrm{T} 3 \mathrm{SS}$-Bla did not result in a reduced ERK phosphorylation in any of the two T cell subsets (Fig. 4b, c). Together, our data suggest that $Y$. pseudotuberculosis can directly interfere with TCR downstream signaling in both naïve $\mathrm{CD} 4^{+} \mathrm{T}$ cells and Foxp3 ${ }^{+}$ Tregs, most likely through translocation of Yops in a T3SSdependent manner.

\section{Modulation of naïve T cells with $Y$. pseudotuberculosis supports the differentiation of Th17 cells, but disturbs de novo induction of Foxp3 ${ }^{+}$Tregs}

Having demonstrated that $Y$. pseudotuberculosis can directly modulate early events of TCR downstream signaling, we next asked which consequences this modulation might have on de novo generation of Th17 cells and Foxp $3^{+}$ Tregs. To this end, ex vivo-isolated naïve $\mathrm{CD}^{+} \mathrm{T}$ cells were co-cultured with Yptb-WT-Bla or $\Delta$ T3SS-Bla for $1 \mathrm{~h}$, followed by gentamicin treatment to kill living bacteria. Subsequently, modulated naïve $\mathrm{CD} 4^{+} \mathrm{T}$ cells were stimulated in vitro in an antigen-presenting cell (APC)-free system under polarizing conditions. Stimulation of Yptb-WTBla-modulated naïve $\mathrm{CD}^{+}{ }^{+} \mathrm{T}$ cells under Th17-polarizing conditions resulted in a significantly enhanced frequency of $\mathrm{IL}-17^{+}$cells at day 6 of the culture when compared to differentiation of unmodulated naïve $\mathrm{CD} 4^{+} \mathrm{T}$ cells (Fig. 5a), although expression of the lineage specification transcription factor ROR $\gamma$ t remained unaffected (Supplementary Fig. S3). Importantly, this enhanced Th17 differentiation was strictly dependent on the T3SS as modulation of CD4 ${ }^{+}$
$\mathrm{T}$ cells with $\Delta \mathrm{T} 3 \mathrm{SS}$-Bla did not result in an increased frequency of Th17 cells.

The opposite was observed when Yptb-WT-Bla-modulated naïve $\mathrm{CD}^{+}{ }^{+} \mathrm{T}$ cells were stimulated under Treginducing conditions. Here, we saw a significantly reduced frequency of Foxp $3^{+}$Tregs at day 4 of the culture when compared to differentiation of unmodulated naïve $\mathrm{CD} 4^{+} \mathrm{T}$ cells (Fig. 5b). Also this disturbance of in vitro Treg differentiation was dependent on the T3SS as no impact could be observed upon modulation of naïve $\mathrm{CD} 4^{+} \mathrm{T}$ cells with $\Delta$ T3SS-Bla (Fig. 5b). Importantly, Y. pseudotuberculosis did not modulate the capacity of naïve $\mathrm{CD}^{+} \mathrm{T}$ cells to differentiate into IFN- $\gamma$-producing cells as no difference in frequencies of IFN- $\gamma^{+}$cells was observed in Th0 or Th1 cultures when Yptb-WT-Bla-modulated naïve $\mathrm{CD} 4^{+} \mathrm{T}$ cells were directly compared with unmodulated cells (Supplementary Fig. S4).

Together, these in vitro data suggest that the direct T3SS-dependent modulation of TCR downstream signaling within naïve $\mathrm{CD} 4^{+} \mathrm{T}$ cells alters their differentiation potential, resulting in a skewing from suppressive Foxp $3^{+}$Tregs to proinflammatory Th17 cells.

\section{Discussion}

In the intestine, the balance between effector and regulatory pathways needs to be tightly controlled in order to maintain immune homeostasis and efficiently combat infections. Therefore, the ability of $\mathrm{CD}^{+}{ }^{+} \mathrm{T}$ cells to change their phenotype and to acquire special functional properties might be critical during acute infection with enteropathogenic $Y$. pseudotuberculosis. Here, we report that Yersiniae selectively disrupt the balance between Tregs and Th17 cells, towards an increased differentiation of proinflammatory Th17 cells and a reduction in the generation of immunosuppressive Tregs, whereas the frequency of IFN- $\gamma$-producing Th1 cells or IL-10-producing $\mathrm{T}$ cells remained largely unaltered. The Yersinia-mediated support of proinflammatory responses is surprising as pathogenic bacteria usually promote Treg expansion, enabling their long-term survival in the host and establishment of chronic infection [31, 32]. However, Yersiniae rather impair efficient de novo Treg induction within gut-draining $\mathrm{mLNs}$, potentially favoring systemic dissemination of the pathogen [17]. Furthermore, increased de novo generation of Th17 cells could support the pathogen in establishing an inflammatory environment via altering microbiota composition, thereby favoring colonization of $Y$. pseudotuberculosis, similar to changes instigated by Citrobacter rodentium and Salmonella infections $[33,34]$. On the other hand, the relatively late appearance of endogenous Th17 cells argues against a microbiotainduced 'innate-like' character, which had been reported 

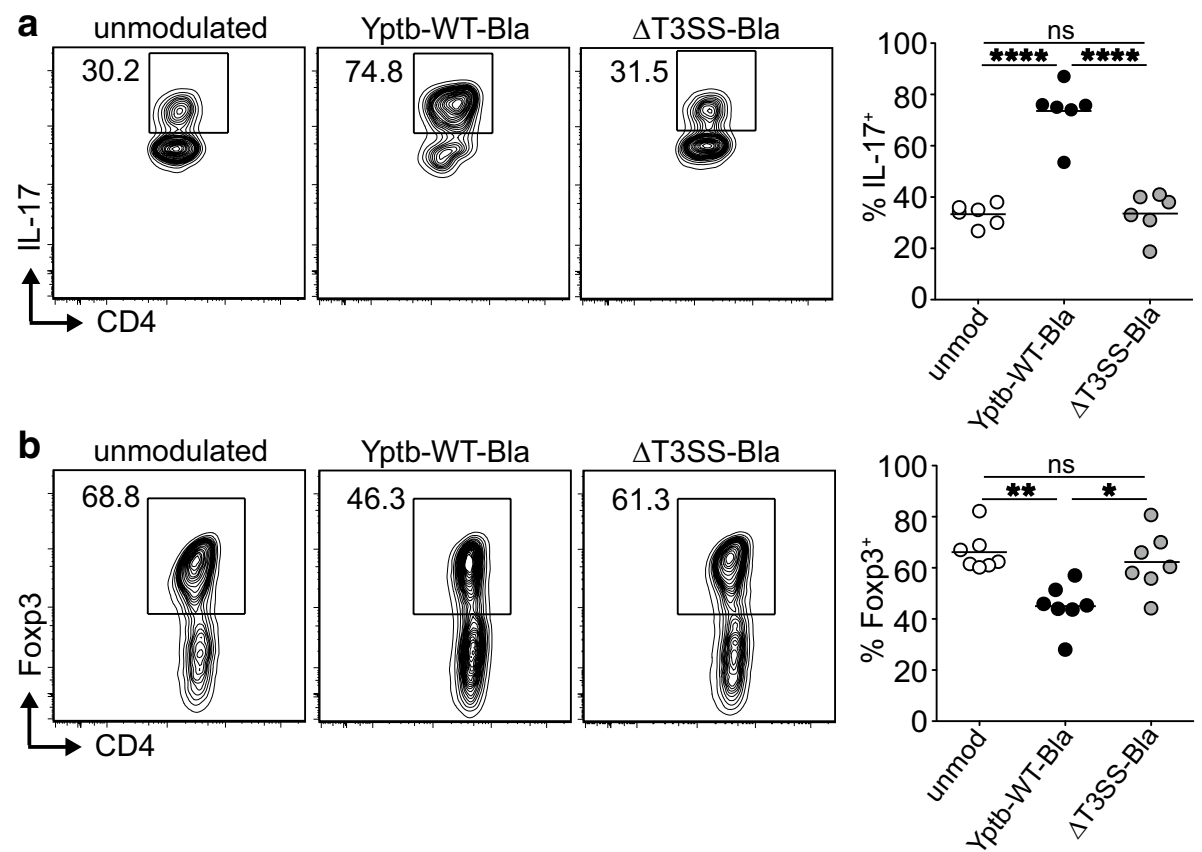

Fig. 5 In vitro modulation of naïve T cells with $Y$. pseudotuberculosis results in increased differentiation of Th17 cells and decreased de novo induction of Foxp $3^{+}$Tregs. Naïve $\mathrm{CD} 4^{+} \mathrm{T}$ cells were enriched from secondary lymphoid organs of Foxp $3^{\mathrm{hCD} 2}$ mice and co-cultured with Yptb-WT-Bla or $\Delta$ T3SS-Bla for $1 \mathrm{~h}$, or were left unmodulated as control. Subsequently, modulated $\mathrm{T}$ cells were cultured under Th17-polarizing or Treg-inducing conditions for 6 or 4 days, respectively, and IL-17 or Foxp3 expression was assessed by flow cytometry

previously [35], but rather suggests that these Th17 cells are pathogen-specific. Thus, our data represent first evidence that Yersiniae disrupt the Th17-Treg balance, which might be a critical strategy of the pathogen in establishing acute infection.

To better understand how Yersiniae fine-tune the $\mathrm{CD} 4^{+}$ $\mathrm{T}$ cell compartment, we characterized DC subsets within mLNs during acute infection. It had been shown before that inflammatory conditions within the gut not only alter the distribution of DCs [36, 37], but also negatively affect the tolerogenic $\mathrm{CD}_{103}{ }^{+}$subset [25], which is known to efficiently promote de novo generation of Foxp $3^{+}$Tregs [23, 26]. Therefore, we first hypothesized that $Y$. pseudotuberculosis indirectly affects $\mathrm{T}$ cell differentiation via modulation of DC subsets within mLNs. Indeed, the strongly decreased frequency of tolerogenic $\mathrm{CD} 103^{+} \mathrm{CD} 8^{+}$DCs could account for reduced Treg induction [23, 24, 38], although it cannot be formally excluded that the reduced frequency of $\mathrm{CD} 103^{-} \mathrm{CD} 8^{+} \mathrm{DCs}$, which most probably belong to resident DCs [27] and for which a tolerogenic phenotype has been described before [39], are also responsible. In contrast, expansion of the CD103 DC subset might be responsible for increased differentiation of Th17 cells $[24,40]$. Interestingly, in a recently published study at the end of the cultures. Representative dot plots show expression of IL-17 (a) and Foxp3 (b) in cells from indicated cultures. Numbers indicate frequencies of cells in gates. Scatter plots summarize frequencies of $\mathrm{IL}-17^{+}$(a) and Foxp3 $3^{+}$(b) cells from indicated cultures. Data are pooled from six (a) or seven $\mathbf{b}$ independent experiments, and means of technical replicates are depicted. ${ }^{*} p<0.05$; ${ }^{*} p<0.01$; $* * * * p<0.0001$

chronic infection with $Y$. pseudotuberculosis only resulted in a decreased frequency of $\mathrm{CD} 103^{+} \mathrm{CD} 11 \mathrm{~b}^{+} \mathrm{DCs}$, without affecting any other DC subsets [9]. This is in contrast to data from the present study, where during the acute phase of infection, frequencies of both $\mathrm{CD} 103^{+}$and $\mathrm{CD} 103^{-} \mathrm{DCs}$ were altered by enteropathogenic Yersiniae, and most likely these changes jointly contribute to the establishment of a strong inflammatory response. Moreover, increased CD86 expression levels of the latter DC subset demonstrate their highly activated status and suggest the possible involvement of Toll-like receptors (TLRs) in creating a shift towards Th17-dominated immune responses [41-43]. However, it still needs to be investigated whether TLR agonists of $Y$. pseudotuberculosis contribute to the increased Th17 differentiation.

Nonetheless, Yersiniae cannot only affect the DC compartment. Using the $\beta$-lactamase reporter system, we could demonstrate that upon infection via the natural route Yersiniae can directly modulate $\mathrm{CD} 4^{+} \mathrm{T}$ cells within infected $\mathrm{mLNs}$, extending previous findings from a systemic infection model [29]. Interestingly, within the $\mathrm{CD}^{+} \mathrm{T}$ cell population, Tregs were preferentially modulated when compared to naïve $\mathrm{T}$ cells. The increased translocation rate of Yops into Tregs can be explained by the binding of 
$Y$. pseudotuberculosis invasin to $\beta 1$ integrin VLA4 [44], which is expressed at higher levels in Tregs as compared to naïve $T$ cells [45].

When dissecting the mechanism of Yersiniae-dependent Treg modulation and alteration of naïve $\mathrm{T}$ cell differentiation, we observed a stark decline of $\mathrm{Ca}^{2+}$ mobilization after TCR triggering for naïve $\mathrm{CD} 4^{+} \mathrm{T}$ cells, while $\mathrm{Ca}^{2+}$ signaling within Foxp $3^{+}$Tregs was even fully abrogated. In line with reduced $\mathrm{Ca}^{2+}$ mobilization, phosphorylation of ERK was strongly abolished in both naïve CD4 ${ }^{+}$ $\mathrm{T}$ cells and Foxp ${ }^{+}$Tregs. Since $\Delta$ T3SS-Bla affected neither $\mathrm{Ca}^{2+}$ signaling nor ERK phosphorylation within both cell types, our findings indicate that direct modulation of $\mathrm{T}$ cells requires the presence of the T3SS. The importance of Yop translocation was also suggested from results of the APC-independent, in vitro $\mathrm{T}$ cell differentiation assay, where increased frequencies of Th17 cells and reduced de novo Treg induction were observed only upon co-culture of naïve T cells with Yptb-WT and not with T3SS-deficient Yersiniae. Among Yops, the tyrosine phosphatase YopH is known to interfere with early $\mathrm{T}$ cell receptor signaling events, either via direct phosphorylation of signaling molecules [46-48], or by binding to adaptor proteins, which then target them to signaling complexes [48, 49]. Thus, YopH might be responsible for the reduced $\mathrm{Ca}^{2+}$ mobilization and ERK phosphorylation we observed in $\mathrm{CD}^{+}$ $\mathrm{T}$ cell subsets being modulated by $Y$. pseudotuberculosis. Moreover, ERK activity in Jurkat $\mathrm{T}$ cells had been restored by addition of a YopH inhibitor [50], further arguing for the involvement of YopH in the reduction of ERK phosphorylation of both naïve $\mathrm{CD} 4^{+} \mathrm{T}$ cells and Foxp $3^{+}$Tregs. Additionally, the interference of YopH with TCR signaling could also lead to reduced secretion of IL2 [47, 51]. Since IL-2 is a factor critically required for induction of Tregs and at the same time can prevent Th17 differentiation [52, 53], it is tempting to speculate that $Y$. pseudotuberculosismediated alterations in IL-2 production also contribute to the skewing from Tregs to Th17 cells, and the lower frequency of de novo-induced Tregs might enable enhanced generation of Th17 cells. Yet, whether YopH is the master regulator of $Y$. pseudotuberculosis-mediated modulation of $\mathrm{T}$ cell differentiation or other mechanisms contribute to the fine-tuning of the closely related transcriptional regulation of Tregs and Th17 cells $[54,55]$ remains to be elucidated. In this context, it will be also interesting to dissect why modulation of naïve $\mathrm{CD} 4^{+} \mathrm{T}$ cells with Yptb-WT-Bla did only affect expression of the cytokine IL-17 in Th17-polarizing cultures, but not the expression of the Th17 lineage specification factor ROR $\gamma \mathrm{t}$, although under Treg-inducing conditions a severe impact on the expression of the Treg lineage specification factor Foxp3 could be observed.

Taken together, the present study implicates a critical role of $\mathrm{CD}^{+} \mathrm{T}$ cell subsets in the pathomechanism of acute $Y$. pseudotuberculosis infection, showing that this enteropathogen favors the generation of Th17 cells, and in parallel leads to a decline in Treg induction. Our data provide evidence that $Y$. pseudotuberculosis interferes with TCR signaling in both Foxp3 ${ }^{+}$Tregs and naïve $\mathrm{CD} 4^{+} \mathrm{T}$ cells, thereby directly modulating $\mathrm{T}$ cell-mediated immune responses. Efforts to understand the precise pathomechanism of gastric infections could permit the development of future therapeutics for an efficient modulation of the immune system.

Acknowledgements We thank Lothar Groebe for cell sorting, Fabio Pisano for support during infection experiments, Maria Ebel, Tanja Krause, and Karin Paduch for technical assistance. This work was supported by the Deutsche Forschungsgemeinschaft (SFB854 project B16 and SPP1656).

Author contributions MP, DK, AB, JP, JN, RT, JS, FP, and MR performed experiments and interpreted data. MP, PD, and JH designed research, interpreted data, and wrote the manuscript.

\section{Compliance with ethical standards}

Conflict of interests The authors declare no conflict of interests.

Open Access This article is distributed under the terms of the Creative Commons Attribution 4.0 International License (http:// creativecommons.org/licenses/by/4.0/), which permits unrestricted use, distribution, and reproduction in any medium, provided you give appropriate credit to the original author(s) and the source, provide a link to the Creative Commons license, and indicate if changes were made.

\section{References}

1. Balada-Llasat JM, Mecsas J (2006) Yersinia has a tropism for B and $\mathrm{T}$ cell zones of lymph nodes that is independent of the type III secretion system. PLoS Pathog 2(9):e86. doi:10.1371/journal. ppat.0020086

2. Wren BW (2003) The yersiniae-a model genus to study the rapid evolution of bacterial pathogens. Nat Rev Microbiol 1(1):55-64. doi:10.1038/nrmicro730

3. Cornelis GR (2006) The type III secretion injectisome. Nat Rev Microbiol 4(11):811-825. doi:10.1038/nrmicro1526

4. Viboud GI, Bliska JB (2005) Yersinia outer proteins: role in modulation of host cell signaling responses and pathogenesis. Annu Rev Microbiol 59:69-89. doi:10.1146/annurev. micro.59.030804.121320

5. Bliska JB, Wang X, Viboud GI, Brodsky IE (2013) Modulation of innate immune responses by Yersinia type III secretion system translocators and effectors. Cell Microbiol 15(10):1622-1631. doi: $10.1111 / \mathrm{cmi} .12164$

6. Schweer J, Kulkarni D, Kochut A, Pezoldt J, Pisano F, Pils MC, Genth H, Huehn J, Dersch P (2013) The cytotoxic necrotizing factor of Yersinia pseudotuberculosis (CNFY) enhances inflammation and Yop delivery during Infection by activation of Rho GTPases. PLoS Pathog 9(11):e1003746. doi:10.1371/journal. ppat. 1003746

7. Wang X, Parashar K, Sitaram A, Bliska JB (2014) The GAP activity of type III effector YopE triggers killing of Yersinia in 
macrophages. PLoS Pathog 10(8):e1004346. doi:10.1371/journal.ppat.1004346

8. Zhang Y, Tam JW, Mena P, van der Velden AW, Bliska JB (2015) $\mathrm{CCR}^{+}$inflammatory dendritic cells and translocation of antigen by Type III secretion are required for the exceptionally Large $\mathrm{CD}^{+} \mathrm{T}$ cell response to the protective YopE69-77 epitope during Yersinia infection. PLoS Pathog 11(10):e1005167. doi:10.1371/journal.ppat.1005167

9. Fonseca DM, Hand TW, Han SJ, Gerner MY, Glatman Zaretsky A, Byrd AL, Harrison OJ, Ortiz AM, Quinones M, Trinchieri G, Brenchley JM, Brodsky IE, Germain RN, Randolph GJ, Belkaid Y (2015) Microbiota-dependent sequelae of acute infection compromise tissue-specific immunity. Cell 163(2):354-366. doi:10.1016/j.cell.2015.08.030

10. Rosenheinrich M, Heine W, Schmuhl CM, Pisano F, Dersch P (2015) Natural killer cells mediate protection against Yersinia pseudotuberculosis in the mesenteric lymph nodes. PLoS ONE 10(8):e0136290. doi:10.1371/journal.pone. 0136290

11. Bergman MA, Loomis WP, Mecsas J, Starnbach MN, Isberg RR (2009) $\mathrm{CD}^{+} \mathrm{T}$ cells restrict Yersinia pseudotuberculosis infection: bypass of anti-phagocytosis by targeting antigenpresenting cells. PLoS Pathog 5(9):e1000573. doi:10.1371/ journal.ppat.1000573

12. Bergsbaken T, Bevan MJ (2015) Proinflammatory microenvironments within the intestine regulate the differentiation of tissue-resident $\mathrm{CD} 8^{+} \mathrm{T}$ cells responding to infection. Nat Immunol 16(4):406-414. doi:10.1038/ni.3108

13. Autenrieth IB, Tingle A, Reske-Kunz A, Heesemann J (1992) $\mathrm{T}$ lymphocytes mediate protection against Yersinia enterocolitica in mice: characterization of murine T-cell clones specific for $Y$. enterocolitica. Infect Immun 60(3):1140-1149

14. Goubard A, Loiez C, Abe J, Fichel C, Herwegh S, Faveeuw C, Porte R, Cayet D, Sebbane F, Penet S, Foligne B, Desreumaux P, Saito H, Sirard JC, Simonet M, Carnoy C (2015) Superantigenic Yersinia pseudotuberculosis induces the expression of granzymes and perforin by $\mathrm{CD} 4^{+} \mathrm{T}$ cells. Infect Immun 83(5):2053-2064. doi:10.1128/IAI.02339-14

15. Sellge G, Magalhaes JG, Konradt C, Fritz JH, Salgado-Pabon W, Eberl G, Bandeira A, Di Santo JP, Sansonetti PJ, Phalipon A (2010) Th17 cells are the dominant $\mathrm{T}$ cell subtype primed by Shigella flexneri mediating protective immunity. J Immunol 184 (4):2076-2085

16. Barat S, Willer Y, Rizos K, Claudi B, Maze A, Schemmer AK, Kirchhoff D, Schmidt A, Burton N, Bumann D (2012) Immunity to intracellular Salmonella depends on surface-associated antigens. PLoS Pathog 8(10):e1002966. doi:10.1371/journal. ppat. 1002966

17. Wang Z, Friedrich C, Hagemann SC, Korte WH, Goharani N, Cording S, Eberl G, Sparwasser T, Lochner M (2014) Regulatory $\mathrm{T}$ cells promote a protective Th17-associated immune response to intestinal bacterial infection with $C$. rodentium. Mucosal Immunol 7(6):1290-1301. doi:10.1038/mi.2014.17

18. Koch KN, Hartung ML, Urban S, Kyburz A, Bahlmann AS, Lind J, Backert S, Taube C, Muller A (2015) Helicobacter urease-induced activation of the TLR2/NLRP3/IL-18 axis protects against asthma. J Clin Invest 125(8):3297-3302. doi:10.1172/JCI79337

19. Echeverry A, Saijo S, Schesser K, Adkins B (2010) Yersinia enterocolitica promotes robust mucosal inflammatory T-cell immunity in murine neonates. Infect Immun 78(8):3595-3608. doi:10.1128/IAI.01272-09

20. Bolin I, Forsberg A, Norlander L, Skurnik M, Wolf-Watz H (1988) Identification and mapping of the temperature-inducible, plasmid-encoded proteins of Yersinia spp. Infect Immun 56(2):343-348
21. Cording S, Wahl B, Kulkarni D, Chopra H, Pezoldt J, Buettner M, Dummer A, Hadis U, Heimesaat M, Bereswill S, Falk C, Bode U, Hamann A, Fleissner D, Huehn J, Pabst O (2014) The intestinal micro-environment imprints stromal cells to promote efficient Treg induction in gut-draining lymph nodes. Mucosal Immunol 7(2):359-368. doi:10.1038/mi.2013.54

22. Pezoldt J, Pisano F, Heine W, Pasztoi M, Rosenheinrich M, Nuss AM, Pils MC, Prinz I, Förster R, Huehn J, Dersch P (2017) CCR7 deficiency modulates $\mathrm{T}$ cell response and increases susceptibility to Yersinia pseudotuberculosis infection. J Infect Dis. doi:10.1093/infdis/jix037

23. Coombes JL, Siddiqui KR, Arancibia-Carcamo CV, Hall J, Sun CM, Belkaid Y, Powrie F (2007) A functionally specialized population of mucosal $\mathrm{CD}_{103^{+}}$DCs induces Foxp3 $3^{+}$regulatory $\mathrm{T}$ cells via a TGF-beta and retinoic acid-dependent mechanism. J Exp Med 204(8):1757-1764

24. Cerovic V, Houston SA, Scott CL, Aumeunier A, Yrlid U, Mowat AM, Milling SW (2013) Intestinal CD103- ${ }^{-}$dendritic cells migrate in lymph and prime effector T cells. Mucosal Immunol 6(1):104-113. doi:10.1038/mi.2012.53

25. Laffont S, Siddiqui KR, Powrie F (2010) Intestinal inflammation abrogates the tolerogenic properties of MLN CD103 ${ }^{+}$ dendritic cells. Eur J Immunol 40(7):1877-1883. doi:10.1002/ eji.200939957

26. Sun CM, Hall JA, Blank RB, Bouladoux N, Oukka M, Mora JR, Belkaid Y (2007) Small intestine lamina propria dendritic cells promote de novo generation of Foxp3 Treg cells via retinoic acid. J Exp Med 204(8):1775-1785

27. Cerovic V, Bain CC, Mowat AM, Milling SW (2014) Intestinal macrophages and dendritic cells: what's the difference? Trends Immunol 35(6):270-277. doi:10.1016/j.it.2014.04.003

28. Marketon MM, DePaolo RW, DeBord KL, Jabri B, Schneewind O (2005) Plague bacteria target immune cells during infection. Science 309(5741):1739-1741. doi:10.1126/science.1114580

29. Koberle M, Klein-Gunther A, Schutz M, Fritz M, Berchtold S, Tolosa E, Autenrieth IB, Bohn E (2009) Yersinia enterocolitica targets cells of the innate and adaptive immune system by injection of Yops in a mouse infection model. PLoS Pathog 5(8):e1000551. doi:10.1371/journal.ppat.1000551

30. Hickman SP, Yang J, Thomas RM, Wells AD, Turka LA (2006) Defective activation of protein kinase $C$ and Ras-ERK pathways limits IL- 2 production and proliferation by $\mathrm{CD} 4{ }^{+} \mathrm{CD} 25^{+}$regulatory T cells. J Immunol 177(4):2186-2194

31. Smigiel KS, Srivastava S, Stolley JM, Campbell DJ (2014) Regulatory T-cell homeostasis: steady-state maintenance and modulation during inflammation. Immunol Rev 259(1):40-59. doi:10.1111/imr.12170

32. Boer MC, Joosten SA, Ottenhoff TH (2015) Regulatory T-cells at the interface between human host and pathogens in infectious diseases and vaccination. Front Immunol 6:217. doi:10.3389/ fimmu.2015.00217

33. Lupp C, Robertson ML, Wickham ME, Sekirov I, Champion OL, Gaynor EC, Finlay BB (2007) Host-mediated inflammation disrupts the intestinal microbiota and promotes the overgrowth of Enterobacteriaceae. Cell Host Microbe 2 (3):204

34. Santos RL, Raffatellu M, Bevins CL, Adams LG, Tukel C, Tsolis RM, Baumler AJ (2009) Life in the inflamed intestine, Salmonella style. Trends Microbiol 17(11):498-506. doi:10.1016/j. tim.2009.08.008

35. Geddes K, Rubino SJ, Magalhaes JG, Streutker C, Le Bourhis L, Cho JH, Robertson SJ, Kim CJ, Kaul R, Philpott DJ, Girardin SE (2011) Identification of an innate T helper type 17 response to intestinal bacterial pathogens. Nat Med 17(7):837-844. doi:10.1038/nm.2391

36. Siddiqui KR, Laffont S, Powrie F (2010) E-cadherin marks a subset of inflammatory dendritic cells that promote $\mathrm{T}$ 
cell-mediated colitis. Immunity 32(4):557-567. doi:10.1016/j. immuni.2010.03.017

37. Magnusson MK, Brynjolfsson SF, Dige A, Uronen-Hansson H, Borjesson LG, Bengtsson JL, Gudjonsson S, Ohman L, Agnholt J, Sjovall H, Agace WW, Wick MJ (2016) Macrophage and dendritic cell subsets in IBD: $\mathrm{ALDH}^{+}$cells are reduced in colon tissue of patients with ulcerative colitis regardless of inflammation. Mucosal Immunol 9(1):171-182. doi:10.1038/mi.2015.48

38. Moretto MM, Harrow DI, Hawley TS, Khan IA (2015) Interleukin-12-producing $\mathrm{CD}_{103}{ }^{+} \mathrm{CD} 11 \mathrm{~b}^{-} \mathrm{CD} 8^{+}$dendritic cells are responsible for eliciting gut intraepithelial lymphocyte response against Encephalitozoon cuniculi. Infect Immun 83(12):47194730. doi:10.1128/IAI.00820-15

39. Nakahara T, Uchi H, Lesokhin AM, Avogadri F, Rizzuto GA, Hirschhorn-Cymerman D, Panageas KS, Merghoub T, Wolchok JD, Houghton AN (2010) Cyclophosphamide enhances immunity by modulating the balance of dendritic cell subsets in lymphoid organs. Blood 115(22):4384-4392. doi:10.1182/ blood-2009-11-251231

40. Scott CL, Bain CC, Wright PB, Sichien D, Kotarsky K, Persson EK, Luda K, Guilliams M, Lambrecht BN, Agace WW, Milling SW, Mowat AM (2015) CCR2 ${ }^{+} \mathrm{CD} 103^{-}$intestinal dendritic cells develop from DC-committed precursors and induce interleukin-17 production by T cells. Mucosal Immunol 8(2):327-339. doi:10.1038/mi.2014.70

41. Depaolo RW, Kamdar K, Khakpour S, Sugiura Y, Wang W, Jabri B (2012) A specific role for TLR1 in protective TH17 immunity during mucosal infection. J Exp Med. doi:10.1084/jem.20112339

42. Uematsu S, Fujimoto K, Jang MH, Yang BG, Jung YJ, Nishiyama M, Sato S, Tsujimura T, Yamamoto M, Yokota Y, Kiyono H, Miyasaka M, Ishii KJ, Akira S (2008) Regulation of humoral and cellular gut immunity by lamina propria dendritic cells expressing Toll-like receptor 5. Nat Immunol 9(7):769-776. doi:10.1038/ni0.1622

43. Van Maele L, Carnoy C, Cayet D, Songhet P, Dumoutier L, Ferrero I, Janot L, Erard F, Bertout J, Leger H, Sebbane F, Benecke A, Renauld JC, Hardt WD, Ryffel B, Sirard JC (2010) TLR5 signaling stimulates the innate production of IL-17 and IL-22 by $\mathrm{CD} 3^{\text {neg }} \mathrm{CD} 127^{+}$immune cells in spleen and mucosa. J Immunol 185(2):1177-1185. doi:10.4049/jimmunol.1000115

44. Ennis E, Isberg RR, Shimizu Y (1993) Very late antigen 4-dependent adhesion and costimulation of resting human $T$ cells by the bacterial beta 1 integrin ligand invasin. J Exp Med 177(1):207-212

45. Huehn J, Siegmund K, Lehmann JC, Siewert C, Haubold U, Feuerer M, Debes GF, Lauber J, Frey O, Przybylski GK, Niesner $\mathrm{U}$, de la Rosa M, Schmidt CA, Brauer R, Buer J, Scheffold A, Hamann A (2004) Developmental stage, phenotype, and migration distinguish naive- and effector/memory-like $\mathrm{CD}^{+}$ regulatory T cells. J Exp Med 199(3):303-313. doi:10.1084/ jem.20031562jem.20031562

46. Alonso A, Bottini N, Bruckner S, Rahmouni S, Williams S, Schoenberger SP, Mustelin T (2004) Lck dephosphorylation at Tyr-394 and inhibition of $\mathrm{T}$ cell antigen receptor signaling by Yersinia phosphatase YopH. J Biol Chem 279(6):4922-4928. doi:10.1074/jbc.M308978200

47. Sauvonnet N, Lambermont I, van der Bruggen P, Cornelis GR (2002) YopH prevents monocyte chemoattractant protein 1 expression in macrophages and $\mathrm{T}$-cell proliferation through inactivation of the phosphatidylinositol 3-kinase pathway. Mol Microbiol 45(3):805-815

48. de la Puerta ML, Trinidad AG, del Carmen Rodriguez M, Bogetz J, Sanchez Crespo M, Mustelin T, Alonso A, Bayon Y (2009) Characterization of new substrates targeted by Yersinia tyrosine phosphatase YopH. PLoS ONE 4(2):e4431. doi:10.1371/journal. pone. 0004431

49. Gerke C, Falkow S, Chien YH (2005) The adaptor molecules LAT and SLP-76 are specifically targeted by Yersinia to inhibit $\mathrm{T}$ cell activation. J Exp Med 201(3):361-371. doi:10.1084/ jem. 20041120

50. Liang F, Huang Z, Lee SY, Liang J, Ivanov MI, Alonso A, Bliska JB, Lawrence DS, Mustelin T, Zhang ZY (2003) Aurintricarboxylic acid blocks in vitro and in vivo activity of YopH, an essential virulent factor of Yersinia pestis, the agent of plague. J Biol Chem 278(43):41734-41741. doi:10.1074/jbc.M307152200

51. Yao T, Mecsas J, Healy JI, Falkow S, Chien Y (1999) Suppression of $\mathrm{T}$ and $\mathrm{B}$ lymphocyte activation by a Yersinia pseudotuberculosis virulence factor, yopH. J Exp Med 190(9):1343-1350

52. Vang KB, Yang J, Mahmud SA, Burchill MA, Vegoe AL, Farrar MA (2008) IL-2, -7, and -15, but not thymic stromal lymphopoeitin, redundantly govern $\mathrm{CD} 4{ }^{+} \mathrm{Foxp}^{+}{ }^{+}$regulatory $\mathrm{T}$ cell development. J Immunol 181(5):3285-3290

53. Laurence A, Tato CM, Davidson TS, Kanno Y, Chen Z, Yao Z, Blank RB, Meylan F, Siegel R, Hennighausen L, Shevach EM, O'Shea JJ (2007) Interleukin-2 signaling via STAT5 constrains $\mathrm{T}$ helper 17 cell generation. Immunity 26(3):371-381. doi:10.1016/j.immuni.2007.02.009

54. Lu D, Liu L, Ji X, Gao Y, Chen X, Liu Y, Liu Y, Zhao X, Li Y, Li Y, Jin Y, Zhang Y, McNutt MA, Yin Y (2015) The phosphatase DUSP2 controls the activity of the transcription activator STAT3 and regulates TH17 differentiation. Nat Immunol 16(12):1263-1273. doi:10.1038/ni.3278

55. Mirlekar B, Ghorai S, Khetmalas M, Bopanna R, Chattopadhyay $S$ (2015) Nuclear matrix protein SMAR1 control regulatory T-cell fate during inflammatory bowel disease (IBD). Mucosal Immunol 8(6):1184-1200. doi:10.1038/mi.2015.42 